\title{
Acute Myocardial Infarction (AMI) and Intermediate Coronary Syndrome (ICS)
}

\author{
E. Stoupel ${ }^{1,2}$, A. Tamoshiunas ${ }^{3}$, R. Radishauskas ${ }^{3}$, G. Bernotiene ${ }^{3}$, E. Abramson ${ }^{4}$, J.Sulkes ${ }^{4}$, \\ P. Israelevich ${ }^{5}$
}

1 Division of Cardiology, Rabin Medical Center, Petah Tiqwa, Israel
2Sackler Faculty of Medicine, Tel Aviv University, Israel
${ }^{3}$ Institute of Cardiology, University of Medicine, Kaunas, Lithuania
${ }^{4}$ Informatics \& Epidemiology Unit Rabin Medical Center, Petah Tiqwa, Israel
${ }^{5}$ Department of Geophysics \& Planetary Sciences, Tel Aviv University, Israel

Received 17 November 2009; revised 17 December 2009; accepted 21 December 2009.

\begin{abstract}
In recent studies it was shown that blood coagulation and inflammation markers are raising at high geomagnetic activity; acute myocardial infarction and all his subtypes, mostly related to atheromatous plaque disruption with higher Cosmic Ray (Neutron) activity. The aim of this study was to explore AMI and ICS differences by concomitant physical conditions, accompanying each of these acute coronary syndromes. The data was a part of MONICA international study in Kaunas, Lithuania in years 2000-2005 (72 consecutive months). 4633 patients with AMI (2461 men) and 961 with ICS (654 men), (age up to 65) were studied. For comparison four indices of Solar (SA), three of Geomagnetic (GMA), Cosmic Ray (CRA) measured by Neutron activity imp/min. were used. Cosmophysical data were from space science institutions in the USA and Russia. Pearson correlation coefficients and their probabilities were obtained.Monthly number of AMI and ICS shows different links with the physical parameters: AMI were significantly inverse related to $S A(r=-0.4, p=0.0021)$ and direct to CRA (Neutron) activity $(r=0.23, p=0.048)$. ICS was not correlated with these two parameters, but show significant links to GMA ( $r=0.25$, $\mathrm{p}=0.037$ ). Gender differences were evident, men more close related to changes in the mentioned physical parameters.Conclusion: 1. Monthly number of AMI and ICS is different related to fluctuations of environmental physical parameters. 2. The described connections can affect differences in the pathogenesis of these forms of Acute Coronary Insufficiency.
\end{abstract}

Keywords: Acute Myocardial Infarction; Intermediate Coronary Syndrome; Geomagnetic;
Cosmic Ray; Neutron Activity

\section{INTRODUCTION}

Acute Coronary Syndrome includes many forms of acute coronary insufficiency. Some related to clinical variants connected to myocardial ischemia-blood supply deficit due to, mostly, atherothrombosis, but also coronary artery spasm, blood losses, vasculitis etc. As a result a number of clinical manifestations of coronary insufficiency take place: pain (Anginal pain), cardiac arrhythmia, resulting in many cases Sudden Cardiac Death, Heart Failure etc. These symptoms can be short, resulting in angina pectoris attacks (AP), and longer and more severe, but remaining without significant myocardial damage named Intermediate Coronary Syndrome (ICS) The drop of blood supply and provoked oxygen and other vital agents disballance for a longer time (mostly more than 20 minutes) often lead to necrobiosis in the area of the damaged (culprit) artery with a specific additional complex of symptoms:(clinical, electrocardiographic, enzymatic) and result in later scar formation, or myocardial rupture, life threatening arrhythmias, aneurysm formation, heart failure that is considered as Acute myocardial Infarction (AMI).The ICS takes place between AP and AMI. Recent studied demonstrated significant links between a number of pathogenetic factors involved in ACS development and environmental physical activity [1-9]. The aim of this study was to explore AMI and ICS (code I21-I22 versus I20, ICD 10) by differences in concomitant environmental physical conditions: Geomagnetic, Solar and Cosmic Ray (Neutron) activity.

\section{PATIENTS AND METHODS}

1) 4633 patients with $\mathrm{AMI}(2461,53.12 \%$ men) age up 
Table 1. Number of stenotic arteries and their maximal stenosis (percentage) in patients with AMI (n-572) and ICS (n-86). Kaunas, Lithuania, 2000-2005.

\begin{tabular}{ccccc}
\hline Code ICD-10 & $\begin{array}{c}\text { Maximal Coronary } \\
\text { Stenosis (\%) }\end{array}$ & $\mathbf{1}$ artery (\%) & $\mathbf{1 + 2}$ arteries (\%) & $\begin{array}{c}\text { 3 and more ar- } \\
\text { teries }(\%)\end{array}$ \\
\hline \multirow{2}{*}{ 121-122 AMI } & less than 70 & 46.9 & 81.3 & 18.8 \\
& $70-99$ & 26.3 & 51.5 & 48.5 \\
& 100 & 22.0 & 51.2 & 48.8 \\
\hline 120.0 ICS & 121-122 Total & 24.8 & 53.0 & 47.0 \\
\hline \multirow{2}{*}{ 120.0Total } & less than 70 & 55.0 & 80.0 & 20.0 \\
Grand Total & $70-99$ & 17.5 & 42.5 & 57.5 \\
& 100 & 23.1 & 38.5 & 61.5 \\
\end{tabular}

to $75 y$. and 961 ICS $(654,68.05 \%$ men) — age up to $65 y$. treated in Kaunas, Lithuania hospitals at years 20002005-72 consecutive months-were included in this study. The registry was part of the international MONICA study registry. In addition, we studied coronary angiography data of 572 patients with AMI (code121-122, ICD 10) and 86 with ICS (code120, ICD 10) comparing the number of stenotic coronary arteries in both groups (1, $1+2$ artery and 3 and more artery disease) and degree of coronary artery stenosis: $<70 \%, 70-99 \%$ and $100 \%$.

2) The monthly distribution of acute cardiovascular events was compared with concomitant four Solar Activity (SA) indices, three Geomagnetic activity indices (GMA) and their antagonist on Earth action-Cosmic Ray activity indices (CRA) presented by Neutron monitoring at the Earth surface in imp/min. Monthly comparison was chosen because the precise time of the beginning of the studied clinical events is difficult to fix hourly or daily and some differences in time of arrival to the surface of our planet of Solar activity elements- particles and wave energy components.

3) The physical data was obtained from the Space Science institutions in the USA, Russia and Finland. [10-16]

4) Pearson correlation coefficients $r$ and their probabilities $\mathrm{p}$ were established for monthly AMI and ICS number and the mentioned cosmophysical indices. Probabilities of $95 \%$ and higher were described as significant; of $90 \%-94 \%$ - as a strong trend toward significance. Comparing the number of narrowed coronary arteries in AMI and ICS groups $\mathrm{Chi}^{2}$ analysis was used, comparing pathology location and severity; 95\% and higher probability in differences was accepted as significant.

\section{RESULTS}

We made some attempts compare the character of coronary lesions resulting in AMI and ICS in this relatively young population group (in accord to MONICA protocol).
The age average of the studied patients was $69.12 \pm$ 12.123 y. for AMI $(64.98 \pm 12.21$ for men, $73.81 \pm 10.17$ for women), woman 9 years older and $55.15 \pm 7.07 \mathrm{y}$. for ICS ( $54.1 \pm 7.5 y$. for men and $57.38 \pm 5.5$ for woman), woman 3 years older.

Table 1 presents the number of affected by narrowing (mostly by atherothrombosis) in both groups. In the AMI group the distribution (in the coronary angiography tested population) was 1 vessel $24.8 \%, 1-2$ vessels $-53.0 \%$ and 3 and more vessel disease in $47.0 \%$. In the ICS group the same distribution included $25.2 \% ; 52.5 \%$ and $47.4 \%$ of patients. It's difficult to imagine more similar results.

Table 2 presents data about maximal coronary artery stenoses in both groups: less that 70\%, 70-99\% and $100 \%$ occlusion. In the AMI group it was only $32(5.6 \%)$ of maximal stenoses less than $70 \%$. In the ICS (despite not high number of invasive verification) were 20 (23.3\%) of 86. Table 3 presents $70 \%-100 \%$ and $100 \%$ ratio in the AMI and ICS groups. 540 of $572(94.4 \%)$ patients in the AMI group had maximal stenoses of $70 \%-100 \%$ versus $76.7 \%$ (66 of 86 patients) in the ICS group, $\mathrm{Chi}^{2}=27.85$, $\mathrm{p}<0.0001$. Comparing total $(100 \%)$ occlusion in both groups we found $346(60.5 \%)$ in the AMI group and 26 $(30.2 \%)$ in ICS, $\mathrm{Chi}^{2}=32.04, \mathrm{p}<0.0001$. Table 4 presents the interrelationship of both groups of acute cardiac events with three groups of monthly space physical activity parameters SA, GMA, CRA. The AMI group was inverse correlated (not strong, but significantly) with SA and related to CRA (Neutron) activity. A different picture was seen in the ICS: absence of significant links with SA and CRA (Neutron) activity and links with GMA in the whole group and men. Absence of such connections in the woman group that was also more than twice smaller, and relatively young.

\section{DISCUSSION}

AMI and ICS, despite many similarities in the etiology, pathogenesis and natural history have also principal dif- 
Table 2. Distribution of maximal coronary stenoses (\%) and number of stenotic coronary arteries in patients with AMI (n-572) and ICS (n-86). Coronary angiography data, 2000- 2005, Kaunas, Lithuania.

\begin{tabular}{|c|c|c|c|c|c|c|}
\hline Code ICD-10 & $\begin{array}{c}\text { Maximal Coro- } \\
\text { nary Stenosis (\%) }\end{array}$ & $\begin{array}{l}1 \text { artery } \\
\text { disease }\end{array}$ & 2 artery disease & $\begin{array}{l}3 \text { artery dis- } \\
\text { ease }\end{array}$ & $\begin{array}{l}4 \text { and more } \\
\text { artery dis- } \\
\text { ease }\end{array}$ & Total \\
\hline \multirow[t]{3}{*}{ 121-122 AMI } & less than 70 & 15 & 11 & 5 & 1 & 32 \\
\hline & 70-99 & 51 & 49 & 51 & 43 & 194 \\
\hline & 100 & 76 & 101 & 84 & 85 & 346 \\
\hline \multicolumn{2}{|c|}{ 121-122 Total } & 142 & 161 & 140 & 129 & 572 \\
\hline \multirow[t]{3}{*}{ 120. ICS } & less than 70 & 11 & 5 & 3 & 1 & 20 \\
\hline & 70-99 & 7 & 10 & 11 & 12 & 40 \\
\hline & 100 & 6 & 4 & 4 & 12 & 26 \\
\hline 120.0 Total & & 24 & 19 & 18 & 25 & 86 \\
\hline Grand Total & & 166 & 180 & 158 & 154 & 658 \\
\hline
\end{tabular}

Table 3. Differences in maximal coronary stenoses and number of stenotic coronary arteries in patient with AMI (n-572) and ICS (n-86).

\begin{tabular}{|c|c|c|c|c|c|c|c|c|}
\hline \multicolumn{9}{|c|}{ Coronary Angiography Data, 2000 - 2005, Kaunas, Lithuania } \\
\hline Diagnoses & $\begin{array}{c}\text { Maximal } \\
\text { Stenosis } \\
(\%)\end{array}$ & $\begin{array}{l}1 \text { artery dis- } \\
\text { ease }\end{array}$ & $\begin{array}{l}2 \text { artery dis- } \\
\text { ease }\end{array}$ & $\begin{array}{l}3 \text { artery dis- } \\
\text { ease }\end{array}$ & $\begin{array}{l}4 \text { and more } \\
\text { artery disease }\end{array}$ & Total & & $\begin{array}{l}\text { fferences \& } \\
\text { robabilities }\end{array}$ \\
\hline AMI & $70-99$ & 89.4 & 93.2 & 96.4 & 99.2 & 94.4 & \multirow{2}{*}{\}} & \multirow{2}{*}{$\begin{array}{l}\mathrm{Chi}^{2}=27.85, \\
\mathrm{p}<0.0001\end{array}$} \\
\hline ICS & $70-99$ & 54.2 & 73.7 & 83.3 & 96.0 & 76.7 & & \\
\hline AMI & 100 & 53.5 & 62.7 & 60.0 & 65.9 & 60.5 & \multirow{2}{*}{\}} & \multirow{2}{*}{$\begin{array}{l}\mathrm{Chi}^{2}=32.04, \\
\text { p }<0.0001\end{array}$} \\
\hline ICS & 100 & 25.0 & 21.1 & 22.2 & 48.0 & 30.2 & & \\
\hline
\end{tabular}

Table 4. Data about AMI and ICS environmental Links. KaunaS, 2000 - 2005 pearson correlation coefficients (r) and their probabilities (p), 72 months data.

\begin{tabular}{|c|c|c|c|c|c|c|}
\hline & \multicolumn{3}{|c|}{ Code 121-122 - AMI } & \multicolumn{3}{|c|}{ Code 120.0 - ICS } \\
\hline & Male & Female & Total & Male & Female & Total \\
\hline $\begin{array}{l}\text { Year } \\
\text { Month 1-12 }\end{array}$ & $\begin{array}{c}0.3 \\
\mathrm{p}=0.019\end{array}$ & $\begin{array}{c}0.29 \\
\mathrm{p}=0.013\end{array}$ & $\begin{array}{c}0.4 \\
\mathrm{p}=0.0017\end{array}$ & N.S. & N.S. & N.S. \\
\hline Sunspot Number & $\begin{array}{c}-0.3 \\
\mathrm{p}=0.01\end{array}$ & $\begin{array}{c}-0.263 \\
\mathrm{p}=0.025\end{array}$ & $\begin{array}{c}-0.4 \\
\mathrm{p}=0.0021\end{array}$ & N.S. & N.S. & N.S. \\
\hline $\begin{array}{l}\text { Smoothed } \\
\text { Sunspot Number }\end{array}$ & $\begin{array}{c}-0.3 \\
\mathrm{p}=0.02\end{array}$ & $\begin{array}{c}-0.3 \\
\mathrm{p}=0.015\end{array}$ & $\begin{array}{l}-0.355 \\
0.0022\end{array}$ & N.S. & N.S. & N.S. \\
\hline $\begin{array}{l}\text { Solar Flux } \\
2800 \text { MGH } 10.7 \mathrm{~cm}\end{array}$ & $\begin{array}{c}-0.3 \\
\mathrm{p}=0.01\end{array}$ & $\begin{array}{c}-0.2 \\
\mathrm{p}=0.096\end{array}$ & $\begin{array}{c}-0.32 \\
p=0.0066\end{array}$ & N.S. & N.S. & N.S. \\
\hline $\begin{array}{l}\text { Adjusted } \\
\text { Solar Flux }\end{array}$ & $\begin{array}{c}-0.3 \\
\mathrm{p}=0.01\end{array}$ & $\begin{array}{c}-0.22 \\
p=0.067\end{array}$ & $\begin{array}{c}-0.33 \\
\mathrm{p}=0.004\end{array}$ & N.S. & N.S. & N.S. \\
\hline \multicolumn{7}{|l|}{ GMA Indices: } \\
\hline Ap. & N.S. & N.S. & N.S. & $\begin{array}{c}0.3 \\
\mathrm{p}=0.027\end{array}$ & N.S. & $\begin{array}{c}0.245 \\
\mathrm{p}=0.037\end{array}$ \\
\hline Cp. & N.S. & N.S. & N.S. & $\begin{array}{c}0.3 \\
\mathrm{p}=0.028\end{array}$ & N.S. & $\begin{array}{c}0.24 \\
\mathrm{p}=0.043\end{array}$ \\
\hline Am. & N.S. & N.S. & N.S. & $\begin{array}{c}0.3 \\
\mathrm{p}=0.01\end{array}$ & N.S. & $\begin{array}{c}0.25 \\
\mathrm{p}=0.037\end{array}$ \\
\hline $\begin{array}{l}\text { Cosmic Ray } \\
\text { Activity }\end{array}$ & $\begin{array}{c}0.2 \\
\mathrm{p}=0.10\end{array}$ & $\begin{array}{l}0,17 \\
\text { N.S. }\end{array}$ & $\begin{array}{c}0.23 \\
\mathrm{p}=0.048\end{array}$ & N.S. & N.S. & N.S. \\
\hline Patients Number & 2461 & 2172 & 4633 & 654 & 307 & 961 \\
\hline
\end{tabular}


ferences. In both types of Acute Coronary Syndrome (ACS) the role of lipid abnormalities, atheromatous plaque formation in the coronary arteries is evident [17-23]. In the last decades the role of inflammation in the development of ACS is widely discussed and mostly accepted [19,21]. The role of thrombosis and endothelial function abnormalities is presented in many studies [21, 20,24].

The cell death of myocytes-necrobiosis and related acute changes in the necrosis area of supplying the culprit artery artery is in $75 \%$ provoked by plaque rupture or fissuring with concomitant thrombosis and occlusion, resulting extreme oxygen transport supply disruption and leading to cell death, rise of specific enzyme, if prolonged about 20 minutes or longer are components characteristic for AMI [21,24,25]. In ICS very similar events of atheromatous-thrombothic narrowing in the coronary arteries are accompanied by signs of clinical, ECG, Echocardiography changes related to drop of myocardial oxygen supply and his functioning, but the component of plaque rupture are rare, complete occlusion of the culprit artery (-ies) not so often and cellular changes mostly reversible [21-25].

In recent years many studies confirmed the role of environmental physical factors-solar, cosmic ray - neutron, geomagnetic, proton flux activity on the timing of occurrence, natural history of many cardiovascular pathologies. The mentioned studies included myocardial infarction, sudden cardiac death, cardiovascular deaths, stroke etc. [26]

In addition, some of risk factors of Coronary Heart Disease like arterial pressure, blood lipids and coagulation, C-reactive protein (CRP), life threatening cardiac arrhythmia (ventricular fibrillation, tachycardia), atrial fibrillation, cardiac arrhythmia in patients with AMI were studied in relation to accompanying levels of GMA, CRA, SA, Space Proton flux of different energy levels. [1-9, 26-32].

Summary of this data can be expressed as follows: both blood coagulation and inflammation markers, including such urgent signal reactants like Fibrinogen and CRP, are rising in high GMA.

Also arterial blood pressure monitoring shows similar results.

GMA and SA are inverse related to CRA -Neutron activity $(\mathrm{r}=-0.83-0.84, \mathrm{p}<0.0001$ for $\mathrm{SA}, \mathrm{r}=-0.60, \mathrm{p}<0.0001$ for GMA in 216 consecutive months) [31].

AMI occurrence (mostly associated with atheromaplaque rupture-fissuring $[17,18,20,23,22,25]$ in three separate studies was correlated with CRA-Neutron activity. These findings were confirmed for all subtypes of AMI-STEMI, NSTEMI, Q Wave and Non Q Wave groups. [6,26,9].

CRA was also correlated with SCD as a consequence of AMI, repeated AMI, Myocardial rupture and ather- othrombosis without AMI- sudden coronary deaths prior formation of AMI by postmortem data analysis [26].

Life threatening cardiac arrhythmias, detected by implantable cardioverter-defibrillators, mostly in patients with Ischemic Cardiomyopathy also showed significant links with daily CRA-Neutron activity [29]. Similar correlation was found exploring the culprit artery in AMI for lesions predominantly related to Left Anterior Descending (LAD) coronary artery lesions. LAD related AMI were accompanied by higher Neutron activity [28].

Right ventricular infarction in AMI related to Right Coronary Artery (RCA) atherothrombosis, a form of AMI with higher mortality and AMI of any culprit artery complicated by cardiogenic shock (mortality still about $60 \%$ ) are also linked with higher Neutron (CRA) activity [30]. A recent published study confirmed the changes in enzyme functioning, a key in most metabolic changes accompanying acute coronary events, by elementary particles or radiation [33].

In ICS coronary ischemia event is mostly connected with thrombosis, atheroma and inflammation related vascular narrowing and acute ischemic myocardial event not involving the most critical element- coronary plaque rupture and sudden or additional thrombosis in the ruptured plaque area, resulting acute arterial occlusion and myocyte necrosis-AMI. The presented maximal stenoses levels confirm the predominant total or near total arterial occlusion phenomena in the AMI group compared with the ICS patients. The action of Neutrons is partially explained by their damage to human tissues and cells as they connect free $\mathrm{H}^{+}$radicals, and transformation to Protons, attacking, first of all, the cell nuclei and other cellular structures. Neutron activity on the Earth surface reflects the CRA- the Neutrons are remains of crushed by Cosmic Rays atoms in the higher parts of the Universe beyond the SA and GMA terrestrial effects zone. [34-39]

This is the way for an attempt to explain the differences seen in the physical situation concomitant with the two groups of acute coronary syndrome (ACS). It's clear, that many additional risk factors and ingredients of the pathogenesis are involved. But in this study we concentrated our attention on the role of environmental physical activity. Some limitations of this study can be mentioned:

1) Absence of elderly patients, especially woman patients (older 75 in AMI and 65 in ICS groups.

2) Relatively small group of angiography proved coronary lesions in the ICS patients group; despite this limitation, the number of invasive studied in ICS was enough to obtain statistically significant results comparing with AMI patients.

\section{CONCLUSIONS}

1) Both AMI and ICS patients show significant links by timing to monthly environmental physical activity. 
2) ICS patients show correlation with level of GMA. Patients with AMI - with CRA.

3) These differences can be a result to diminished role of plaque disruption and / or fissuring in ICS compared to AMI.

4) Both groups were similar by number of affected coronary arteries, but AMI patients suffered from more critical and total coronary occlusions.

\section{ACKNOWLEDGEMENTS}

The authors express gratitude to Mr. G.H. Jenkins for his help with the English version of the manuscript. We are very grateful for the financial support from Junta de Castilla y León (JCYL).

\section{REFERENCES}

[1] Stoupel, E., Joshua, H., Lahav, J. (1996) Human blood coagulation parameters and geomagnetic activity. Eur $J$ Int Med, 7, 217-220.

[2] Stoupel, E., Wittenberg, C., Zabludovski, J., Boner, G. (1995) Ambulatory blood pressure monitoring in patients with hypertension on days of high and low geomagnetic activity. J Human Hypertension, 9, 293-294.

[3] Stoupel, E., Abramson, E., Israelevich, P., Sulkes, J., Harell, D. (2007) Dynamics of serum C-reactive protein (CRP) level and cosmophysical activity. Eur J Int Med, 18(2), 124-128.

[4] Stoupel, E. (1980) Solar-terrestrial predictions: Aspects for preventive medicine in: Donnelly Ed. solar-terrestrial predictions. Vol 4. NOAA Space Environment Laboratory and USAF, Boulder, Co., USA, G29-G40.

[5] Oranevskii, V.N., Breus, T.K., Baevskii, R.M., Rappoprt, S.I., Petrov, V.M., Barsukova, Z.V. (1998) Effect of geomagnetic activity on the functional status of the body. Biofizika, 43(5), 819-826.

[6] Stoupel, E., Domarkiene, S., Radishauskas, R., Bernotiene, G., Abramson, E., Israelevich, P., Sulkes, J. (2004) Links between monthly rates of four subtypes of acute myocardial infarction and their corresponding cosmophysical activity parameters. J Basic \& Clin Physiol \& Pharmacol, 15(3-4), 175-184.

[7] Gurfinkel, Y.I., Liubimov, V.V., Orajevskii, V.N., Parfenova, L.M., Yurjev, A.S. (1995) The influence of geomagnetic activity on capillary flow in ischemic heart disease patients. Biofizika, 40(4), 793-799.

[8] Nuzhdina, M.A. (1998) Effect of natural factors on the occurrence of cardiovascular diseases. Biofizika, 43(4) 640-646.

[9] Stoupel, E., Babayev, E., Mustafa, F., Abramson, E., Israelevich, P., Sulkes, J. (2007) Acute myocardial Infarction occurrence: Environmental links - Baku 2003-2005 data. Med Sc Monit, 13(8), BR 175-179.

[10] NOAA National Geophysical Data Center. Solar Indices Bulletin.

[11] NOAA National Geophysical Data Center. Geomagnetic Indices Bulletin.

[12] NOAA, SWPC-USAF Preliminary Report and Forecast of Solar Geophysical Data.

[13] Russian Academy of Sciences. Izmiran Institute. Cosmic Data.

[14] Russian Academy of Sciences. Moscow Neutron Monitoring Data.

[15] Oulu University. Neutron Monitoring Data, 15.

[16] NOAA-USAF. (1988) SESC glossary of solar-terrestrial terms. Boulder, CO, USA, 1-69.

[17] Fuster, V. (1999) The vulnerable atherosclerotic plaque. Blackwell Publishing.

[18] Fuster, V., Fayad, Z.A., Badimon, J.J. (1999) Acute coronary syndromes. Lancet 353, Suppl., 2, S114-119.

[19] Libby, P., Ridker, P.M., Maseri, A. (2002) Inflammation and atherosclerosis. Circulation, 105(9), 1135-1143.

[20] Topol, E. (2005) Atlas of Atherothrombosis. Current Medical Group. 2004 London.

[21] Gawaz, M. (2006) The evolving science of atherothrombotic disease Eur heart J Suppl. Antiplateled Strategies in Patients Undergoing Interventions with Acute Coronary Syndrome Ed. J.-F. Neumann, 10(1), 14-17.

[22] Solem, J., Levin, M., Karlsson, T., Grip, L., Albertson, P., Wiklund, O. (2006) Composition of coronary plaque obtained by directional atherectomy in stable angina: its relation to serum lipids and statin treatment. J Int Med, 259 (3), 267-275.

[23] Tanaka, A., Shimada, K., Numba, M., Sakamoto, T., Nakamura, Y., Nishida, V.Y., Yoshikawa, J., Akasaka, T.M. Relationship between longitudinal.

[24] (2008) Morphology of ruptured plaques and TIMI flow grade in acute coronary syndrome: a three-dimensional intravascular ultrasound imaging study. Eur Heart J, 29, 38-44.

[25] De Catherina, R., Husted, S., Walentin, L. et al. (2007) ESC position paper v. Anticoagulants in heart disease: current status and perspectives. Eur Heart J, 28(7), 880-913.

[26] Thigesen, K., Alpert, J.S. (2007) White HD on behalf the ESC/ACCF/AHA/ WHF task force universal definition of myocardial infarction. European Heart Journal, 28, 2525-2538.

[27] Stoupel, E. (2002) The effect of geomagnetic activity on cardiovascular parameters. Biomedicine \& Pharmacotherapy. 56, 247-256.

[28] Stoupel, E., Domarkiene, S., Radishauskas, R., Abramson, E., Israelevich, P., Sulkes, J. (2006) Neutrons and Sudden Cardiac Deaths (SCD) Codes 121-125 ICD 10. Basic \& Clin Physiol \& Pharmacol, 17(1), 45-53.

[29] Stoupel, E., Assali, A., Teplitzky, I., Abramson, E., Israelevich, P., Sulkes, J. (2008) The culprit artery in acute myocardial infarction in different environmental physical activity levels. Intern J Cardiol, 126, 266-290.

[30] Stoupel, E., Kusniec, J., Mazur, J., Abramson, E., Israelevich, P., Strasberg, B. (2008) Timing of life-threatening arrhythmias detected by implantable cardioverterdefibrillators in relation to changes in cosmophysical factors. Cardiology J, 15(5), 1-4.

[31] Stoupel, E., Assali, A., Teplitzky, I., Vaknin-Assa, H., Abramson, E., Israelevich, P., Kornowski, R. (2009) Physical influences on right ventricular infarction and cardiogenic shock in acute myocardial Infarction. Basic \& 
Clin Physiol \& Pharmacol, 20(1), 83-90.

[32] Stoupel, E., Kalediene, R., Petrauskiene, J., Starkuviene, S., Abramson, E., Israelevich, P., Sulkes, J. (2009) Deathoptimal physical conditions. The 56th Annual Conference of the Israeli Heart Society, Program and Abstracts. 119, 16.

[33] Stoupel, E., Babayev, E., Mustafa, F., Abramson, E., Israelevich, P., Sulkes, J. (2003-2005) (2006) Clinical cosmobiology: Sudden cardiac death and daily /monthly geomagnetic-cosmic ray and solar activity. The Baku Study. Sun \& Geosphere, 1(2), 13-16.

[34] Kirby, A.J., Hollffelder, F. (2008) Enzymes under the nanoscope. Nature, 456(6), 45-47.

[35] Nias, A.H.V. (1999) An introroduction to radiotherapy. John Wiley \& Sons, NY.

[36] The Pierre Auger collaboration. (2007) Correlation of the Highest-Energy Cosmic Rays with Nearby Extragalactic Objects, Science, 318(5852), 938-943.

[37] Johnston, H. (2008) Cosmic-ray mystery solved at last. http://physicsworld.com/cws/article/news/, 31764, 1-3.

[38] Cho, A. (2007) Universe's Highest-Energy Particles Traced Back to Other Galaxies Science, 318, 896-897. www.sciencemag.org (Accessed December 24). 